\title{
Bacteriophage Treatment in Urinary Tract Infections: Is the Old Friend Coming Back?
}

\author{
Esat Korgali \\ Sivas Cumhuriyet University, Faculty of Medicine, Department of Urology \\ Cumhuriyet University Campus, Sivas, Turkey \\ E-mail: estkorgali@gmail.com
}

\begin{abstract}
Urinary tract infections cause serious difficulties and may result in mortality because of limited antibacterial options in last years. This is related to increased resistance of microorganisms, multiple drug resistance and biofilms. For this reason an old way, bacteriophage treatment, gets used as an alternative to antibiotics and/or synergistic combination with antibiotics which makes it start being popular again. Our purpose in this review is to make an update to urinary tract infections' possible treatment method.
\end{abstract}

Keywords: Apriori algorithm, intensive care units, laboratory tests, templates

\section{Special Issue of Health Sciences}

DOI: $10.7176 / \mathrm{JSTR} / 6-03-09$

\begin{abstract}
Özet:
İdrar yolu enfeksiyonları; son y1llarda tedavilerinde kısıtlı antibakteriyel seçenekler nedeniyle ciddi zorluk yaşanan, mortalite ile sonuçlanabilen enfeksiyonlardır. Bu durum, etken mikroorganizmalardaki artan direnç oranları, çoklu ilaç direnci ve mikroorganizmaların biyofilm oluşturması ile ilişkilidir. Bu sebeplerle eski bir tedavi şekli olan bakteriyofaj tedavileri antibiyoterapiye alternatif olarak ve/veya antibiyotikle sinerji oluşturması amacıyla günümüzde tekrar popülerlik kazanmaya başlamışlardır. Bu derlemedeki amacımız idrar yolu enfeksiyonlarının tedavisinde rol alması muhtemel bu tedavi şekli ile ilgili bir güncelleme yapmaktır.
\end{abstract}

\section{Giriş}

İdrar yolu enfeksiyonları (IYYE) toplum kaynaklı bakteriyel enfeksiyonların, özellikle birinci basamak sağlık merkezlerine başvuruların en sık nedenlerinden biridir (1). Tüm dünyada ciddi morbidite, mortalite ve önemli oranlarda finansal kayıplara yol açar. Nozokomial enfeksiyonların ise yaklaşık \%40'ını IYYE oluşturur (2). Nozokomial bakteriyemilerin yaklaşık \%20'si üriner sistem kaynaklıdır ve bu durumla ilişkili mortalite oranı da yaklaşı \%10'dur(3). Günümüzde idrar yolu enfeksiyonları için değişik sınıflama sistemleri kullanılmakla beraber Avrupa Üroloji Derneği IYYE kılavuzunda IYYE’nı komplike olmayan IYYE (sistit, pyelonefrit), komplike İYE (komlike olmayan IYYE dışı tüm IYYE), rekürren IYYE, katater ilişkili IYYE ve ürosepsis olarak sınıflandırılmıştır (4). Aynı kılavuzda her üriner tipine göre temelde antibiyoterapi bazlı çok farklı tedavi seçenekleri önerilmektedir.

IYE'nın etkenleri çok çeşitlidir, en sık etken Escherichia coli (80\%), daha az oranda ise Staphylococcus saprophyticus (10\% to $15 \%$ ), Pseudomonas aeruginosa, Klebsiella, Enterobacter, Enterokoklar, ve Proteus türleridir ayrıca Candida türü mantarlar ve Mycobacterium tuberculosis diğer nadir IYYE etkenleridir(5-7). Tüm dünyada antibiyotiklerin yaygın ve uygunsuz kullanımı nedeniyle dirençli suşların artması global ölçekte endişe verici boyutlardadır(8). Bu etkenlerin oluşturduğu enfeksiyonların tedavisini zorlaştıran ve komplike hale getiren faktörlerden olan antibiyotik direnci antibiyotikleri parçalayan enzimlerin (betalaktamaz) ve /veya biofilm üretimi ile sağlanır. Bu önemli sorun insan sağlı̆̆ açısından büyüyen ve çözülmesi için çeşitli çabalar harcanan bir problem teşkil etmektedir.

Antibiyotik öncesi dönemde d'Herelle'in bakteriyofajları keşfinden sonra 1920'li yıllarda enfeksiyonların tedavisinde bakteriyofajlar kullanılmış, kanıta dayalı tıp için gerekli olan kaliteli faj çalışmalarının yapılması antibiyotiklere göre daha zor olduğu için antibiyotiklerin keşfinden sonra batı dünyasında faj tedavileri popülaritesini kaybetmiş, fajlar sadece gida işleme süreçlerinde kullanılmışlardır. Ancak günümüzde Doğu Avrupa ülkelerinden Gürcistan, Ermenistan, Ukrayna ve Rusya'da faj tedavileri rutinde kullanılmaktadır. Bazı araştırmacılar faj tedavisinin dermatoloji, genel 
cerrahi, yara tedavisi, gastrointestinal sistem enfeksiyonları, oftalmatoloji, jinekoloji ve ürolojide kullanımları ile ilgili derlemeler yayımlamışlardır (9-11).

Son dönemde yaşanan küresel direnç sorunları nedeniyle Avrupa ve Amerika gibi gelişmiş ülkelerde de faj tedavileri gündeme gelmiş art arda bu konuda yeni çalışmalar bildirilmektedir.

Bu derlemeyi hazırlamadaki amacımız yeniden güncellik kazanan faj tedavisinin yeni verilerini gözden geçirmek ve bu tedavinin IYYE'nın tedavisinde oynayabileceği rolü özetlemektir.

\section{Bakteriofaj Tedavisinin Tarihçesi}

Bakteriofajlar ilk olarak 1915 ve 1917 yıllarında birbirinden bağımsız çalışmalar yapan Frederick Twort ve Felix d'Hérelle tarafinda keşfedilmiştir (12-13). Geçtiğimiz yüzyılda Sovyetler Birliği ülkelerinde kullanılan faj terapisi batı dünyasında 1928'de Alexander Flemming'in penisilin G'yi bularak tedavide antibiyotik çağını açması nedeniyle kendine yer bulamadı. Günümüze kadar keşfedilen önemli antibiyotikler penisilinler, sefalosporinler, karbapenemler, tetrasiklinler, makrolidler, linkozamidler, kloramfenikol, aminoglikozidler, glikopeptidler, lipopeptidler, oksazolidinonlar, kinolonlar, polimiksinler ve sülfonamidlerdir. Tümü geçtiğimiz yüzyılda keşfedilmiş olan bu antibiyotikler tıpta devrim yaratmış ve mikroorganizmalara bağlı gelişen mortalite ve morbiditenin önemli derecede azalmasını sağlamıştır. Bununla birlikte patojenik bakterilerin büyük bir kısmının mensup olduğu Enterobacteriaceae ailesi kullanılan antibiyotiklere özellikle son dönemde karbapenemlere dirençli suşlar geliştirmiştir (14). Çoklu ilaç direnci ve yoğun ilaç direnci olan tehlikeli suşlarla mücadelede günümüzde terapotik ajan olarak bakteriyofajların kullanımı son on yılda tekrar gündeme gelmiştir.

\section{Bakteriyofajların Etki Mekanizmaları}

Bakteriyofaj tedavisi fajların konak olarak kullandıkları patojen bakteriyi parçalama prensibine dayanır. Faj bakteri tarafından hücre içine alındıktan sonra bakteriolizis süreci başlar. Bakteriyolizis aşamasında endolizin kullanılıp, kullanılmamasına göre temel 2 süreç işler. Lizozim kullanılan süreçte faj tarafindan üretilen lizozim bakteriyi parçalar. Diğer süreçte ise faj konak bakterinin yaşamsal faaliyetlerini sürdürmesini engelleyerek (hücre duvar sentezinin inhibisyonu) bakterinin parçalanmasını sağlar (15).

\section{Lizozim Bă̆ımsız Sistem}

$\mathrm{Bu}$ tür bakteriofajlar lizozim üretimini sağlayan genlere sahip olamadığı için bakterinin hücre duvar sentezinin inhibisyonunu sağlayan proteini üreterek bakterinin büyümesi sırasında parçalanmasını sağlar. E. Coli'yi hedef alan faj Q $\beta$ ve faj $\varphi$ X174 bu yolla bakteriyi parçalarlar (16-17).

\section{Lizozim Bă̆ımlı Sistem}

Bazı bakteriofajlar lizozim kodlayarak bakteriyi parçalarlar. Bu bakteriofajların yaklaşık \%95'i Caudovirales türünde çift zincir DNA virüsleridir. Bu tür fajlar lizinler ve holinler olmak üzere 2 tür lizozim ekspresyonu yaparak etkili olurlar (18). Holin grubu lizozimler hücre memranında defektler oluşturup hücre içi elektrolit ve sıvı dengesini bozarak etki ederken, endolizin, muralizin, muramidaz veya virolizin olarakta bilinen lizin grubu lizozimler ise direkt hücre membranını parçalayarak litik etkilerini gösterirler (19). Bu yüzden lizin kullanan fajlar bakteriyi tamamen parçalayıp ortadan kaldırırken holistin kodlayan fajların etkili olduğu durumlarda hayalet bakteri denen büyük debrisler kalır (15).

\section{Faj Tedavisinin Üstün Yönleri}

Litik fajlar bakterisidal ajanlar gibi etki ederek bakterileri parçalar ve öldürürler. Fajlar kendi kendilerini replike edebilirler ve bu özellikleri sayesinde tedavi amacı ile çok düşük dozlarda istenen etkinliklerini sağlayabilirler. Konak seçiciliklerinin çok yüksek olması hatta patojene özel fajların kullanılması normal florayı etkilemeksizin ya da minimal etkiyle patojen bakterileri parçalarlar. Fajların doğada yaygın olarak bulunması nedeniyle çevreye olumsuz etkileri yoktur ve çok düşük maliyet ile izole edilerek kullanılması mümkün olur. Bakterilerin direnç geliştirme yöntemlerinin hepsine fajlar da sahiptir. Bu sayede fajlara direnç gelişim oranı antibiyotiklere oranla oldukça düşüktür. Faj tedavisinin en önemli üstünlüklerinden birisi de antibiyotiklerin etki etmesini önleyen biofilm tabakalarını geçerek biofilm yapan mikroorganizmaların tedavisini tek başlarına ya da antibiyotiklerle birlikte sağlamalarıdır (11).

\section{Üropatojenik Mikroroganizmalar İçin Direnç Yönetim Stratejisi Olarak Faj Tedavisi}

Yukarıda saydığımız avantajları nedeniyle bilim dünyasında faj tedavisi çeşitli antibiyotik dirençli şuşların neden olduğu İYE'nın tedavisinde oldukça popüler hale geldi.

Buna ek olarak faj tedavisinin hayvan modelleri üzerindeki etkinliğini gösteren bazı çalışmalar antimikrobiyal ajan olarak kullanılma potansiyellerini ortaya koydu.

68 | P a g e 
Faj tedavileri üzerindeki çalışmalar 4 ana başlık altında ilerlemektedir. Bunlar doğal faj kokteylleri, genetik mühendisliği ürünü fajlar, faj litik enzimleri veya proteinlerinin doğal ve üretilmiş formları, faj ve antibiyotik sinerjisi (11).

Konakçı aralığı fajların enfekte edebileceği türlerin çeşitliliğini yansıtır. Tek faj yerine farklı mikroorganizmaları etkileyebilecek fajların izole edilerek faj kokteyli şeklinde uygulanan faj terapileri konakçı aralığı ve tedavi spektrumunu genişletecektir (22). Nishikawa ve ark. faj kokteylinin etkinliğini araştırdıkları literatürdeki ilk çalışmada, üropatojenik E.coli tedavisinde T4 fajı ve çoklu ilaç direnci olan E. Coli'ye karşı yeni izole edilen KEP10 Fajını birlikte kullanmışlar ve sadece KEP10'un bakteriyolitik spektrumun \%67 olduğunu; T4'ün ise \%14 olduğunu göstermişler iki fajın birlikte kullanılması halinde aynı UPEC (Uropatojenik E. Coli) şusunun farelere intraperitoneal enjekte edildiği modelde uygun terapötik etkiyi sağladıklarını doğrulamışlardır (23). Chibeu ve ark. biofilm oluşturan mikroorganizmalara karşı fajların etkinliklerini araştırdıkları çalışmalarında kendilerinin izole ettikleri fajlardan oluşan 3'lü faj kokteylinin biofilm oluşturan UPEC suşuna karş1 \% 80.5 litik aktivite sağladığını göstermişlerdir (24).

Faj tedavisi planlanırken etkenin farklı reseptörlerini hedefleyen fajların kokteyl şeklinde uygulanması faj dirençli bakteri suşlarının gelişimini geciktirir (11). Cadha ve ark. farelerdeki yanığa bağlı yara enfeksiyonunu tedavisi için tek faj ile faj kokteylinin in vivo etkinliklerini karşılaştırdıkları çalışmalarında kokteyl tedavisinin daha etkin olduğunu ve direnç gelişiminin kokteyl grubunda daha geç olduğunu göstermişleridir (25). Bunun yanı sıra bazı fajlar aynı bakteri üzerinde farklı reseptörleri hedefleyerek litik etki oluşturabilirler. Bu faj türlerine direnç gelişimi de tek reseptör üzerinden etkili olan faj türlerine göre daha geç dönemde olur (11).

UPEC hastane enfeksiyonlarının önemli bir kısmını oluşturan özellikle yoğun bakım hastalarında uzun süreli kateterizasyon nedeniyle gelişen kateter ilişkili üriner sistem enfeksiyonlarında sıklıkla izole edilen etkendir. Kateter yerleştirildikten sonra UPEC suşları bakteriyel adhezinleri sayesinde kateter yüzeyine ve ürotelyuma yerleşerek kolonize olurlar. Bakteriler sonrasında fenotip değişimine uğrayarak kendilerini koruma amacı ile polisakkaritleri üretmeye başlarlar ve biofilm tabakası oluşur. Oluşan bu biofilm tabakası bakteriyi konağın immün siteminden ve antibiyotiklerden korur (26). Bu biofilm tabakası içindeki metabolik aktivitesi azalmış olan bakterilerle mücadele etmek için faj kokteylleri antibiyotiklere göre daha uygun alternatiflerdir. Lehman ve Donlan $P$. aeruginosa ve $P$. Mirabilis gibi biofilm oluşturma yeteneği yüksek olan bakterilere etkili faj kokteyli ( $6 P$. aeruginosa faj1, $4 P$. Mirabilis faj1 ) ile kaplanmış kateterlerde bakteri ile temastan 48 saat sonraki bakteriyel biofilm sayısının faj ile kaplanmamış kateterlere oranla daha az olduğunu gözlemlemişlerdir (27). Benzer olarak daha önce $S$. aureus biofilmleri oluşmuş olan bir katetere faj K ve bunun 6 türünü içeren faj kokteyli uygulandığında 48 saat sonra biofilm oluşumunun tamamen inhibe olarak biofilmin kaybolduğu gözlenmiştir(28).

Doğal fajların hastane ortamında üropatojenlere karşı kullanılması ile ilgili etkili olduğu konakçı aralığının darlığı, fajlara dirençli bakteri suşlarının gelişimi, bakteriyal lizisin zararlı etkileri, hastanın immünolojik durumuna etkisi gibi konularda çekinceler mevcuttur. Bundan dolayı çoklu ilaç direnci olan üropatojenlerin son zamanlarda genetiği değiştirilmiş bakteriyofajlarla tedavisi amacıyla yapılan çalışmalar artarak devam etmektedir (11).

Biyoteknoloji, sentetik ve moleküler biyoloji alanındaki gelişmeler sayesinde fajlara genetik mühendisilik müdahalesi ve genetik modifikasyonlar yapılarak istenen özelliklere sahip, istenmeyen özelliklerin ortadan kaldırıldığı faj tiplerinin dizaynı ve üretimi mümkün olabilmektedir (29). MøllerOlsen ve ark. E. Coli'ye etkili olan K1 Fajının CRISPR-Cas seleksiyon mekanizmasını kullanarak genetiğini değiştirmişler ve bu değişiklik ile yeni oluşan faj KF1 E. coli’nin kapsülünde yer alan K1 polisakkaritini hedef olarak belirlemiş ve bu özellik sayesinde faj ürotelyumda yer alan T24 epitelyal hücreler içine yerleşerek konak savunmasında kaçabilen bakterileri öldürme yeteneği kazanmıştır (29). Faj antibiyotik sinerjiside çoklu ilaç direnci olan üropatojenlerin tedavisinde kullanılabilecek diğer bir stratejik seçenektir. Ortamda düşük dozlarda antibiyotik varlığında konak bakteri içerisindeki faj sayısının arttığı Kim ve ark.'nın yaptığı çalışmada gösterilmiştir. Ortamda stress uyarıcı, sub-inhibitör dozlarda antibiyotik varlığında, ortamda çok düşük miktarlarda faj olsa bile başlangıçta bakteri lizisi gecikir bu gecikme daha sonra bakteri içinde faj üretiminin artmasını sağlar. Sonuçta daha düşük antibiyotik ve faj konsantrasyonları ile daha etkin bir tedavi sağlanır. Her iki tedavi aracının düşük dozlarda kullanılması her ikisine karşı gelişmesi muhtemel olan direnç olasılığını da azaltmaktadır (30).

\section{İdrar Yolu Enfeksiyonlarının Tedavisinde Faj Klinik Çalışmaları}

Bu konudaki klinik çalışmalar, Doğu Avrupa Ülkelerinde faj tedavisi 20. yüzyılın başından beri halen uygulanıyor olmasına rağmen, Batı dünyasının bu tedavi şekline; antibiyotiklerin hızlı gelişimi ve yüz güldürücü etkinlikleri nedeniyle; uzak kalmasından dolayı çok azdır. İlk çalışmalar "'PYO' olarak

$69 \mid \mathrm{P}$ a g e

www.iiste.org 
adlandırılan IYYE etkeni patojenlere karşı adapte edilen faj ile yapılmış ve yan etki olmaksızın başarılı sonuçlar elde edilmiştir (31).

Bu konudaki ilk klinik yayınlardan biri Khavaldeh ve ark.'nın vaka takdimidir. Bu yazıda 67 yaşında adenokanser nedeniyle büyük bir abdominopelvik cerrahi geçiren sonrasında da pelvik radyoterapi uygulanan bilateral üreteral stendi ve mesane ülserasyonu olan kadın hastada gelişen $P$. Aeroginosa'nın etken olduğu IYYE, bu etkene adapte edilmiş 6 fajın kullanıldığı kokteylin antibiyotikle kombinasyonu ile başarılı bir şekilde tedavi edilmiştir (32).

Leitner ve ark. plasebo kontrollü, randomize, çift kör çalışmaları transuretral rezeksiyon uygulanan hastalar 3 gruba birebir randomize edilerek intravezikal uygulanan faj tedavisini plasebo ve antibiyoterapi ile kıyaslamayı amaçlamışlardır. Bu çalışma halen devam etmekte olup çalışmanın verileri henüz yayımlanmamıştır(33). Bu çalışmanın ön çalışması olarak planlanan klinik çalışmada faj tedavisi uygulanan 9 hastanın 6'sında tedavi etkin bir şekilde sağlanmış faj tedavisi uygulanan hastaların hiç birinde güvenlik problemi yaşanmamıştır (31).

\section{Sonuç:}

IYY'ları toplum kökenli ve hastane kaynaklı enfeksiyonların önemli bir kısmını oluşturmaktadır ve artan direnç problemleri nedeniyle antibiyoterapiye alternatif arayışları devam etmektedir. Uzun zamandan beri bilinen bakteriyofaj tedavileri in vitro çalışmalara göre önemli bir seçenek olarak kabul edilmektedir ancak en büyük kısıtlayıcıları yeterli randomize, kontrollü klinik çalışmalarının olmamasıdır. Yeni klinik çalışmaların sonuçları alındığında yeterli klinik veriler eşliğinde bakteriyofaj tedavileri de İYE tedavisinde hak ettikleri yeri alacaklardır.

\section{Referanslar}

1- Hotchandani R, Aggarwal KK (2012) Urinary tract infections in women. Indian J Clin Pract 23:187-192

2- Nuvials X, Palomar M, Alvarez-Lerma F, et al (2015). Health-care associated infections. Patient characteristics and influence on the clinical outcome of patients admitted to ICU. Envin-Helics registry data. Intensive Care Med Exp.;3(Suppl 1):A82

3- Gould, C.V., et al. Guideline for prevention of catheter-associated urinary tract infections 2009.(2010) Infect Control Hosp Epidemiol, 31: 319

4- Bonkat G, Bartoletti R, Bruyére F, et al. EAU guidelines on urological infections 2019. Arnhem, The Netherlands: European Association of Urology; 2019.

5- Flores-Mireles AL, Walker JN, Caparon M, Hultgren SJ (2015) Urinary tract infections: epidemiology, mechanisms of infection and treatment options. Nat Rev Microbiol 13:269-284. https://doi.org/10.1038/nrmicro3432

6- Kline KA, Bowdish DM (2016) Infection in an aging population. Curr Opin Microbiol 29:6367. https://doi.org/10.1016/j.mib.2015.11.003

7- Griebling TL (2004) Urinary tract infection in women. In: Litwin MS, Saigal CS (eds) Urologic diseases in America. US Government Publishing Office, Washington DC, pp 153-183

8- Verbeken,G.,Huys,I.,Pirnay,J.P.,Jennes,S.,Chanishvili,N.,Scheres,J.,etal. Takingbacteriophagetherapyseriously:amoralargument. Biomed.Res.Int. doi: $10.1155 / 2014 / 621316$

9- Abedon,S.T.,Kuhl,S.J.,Blasdel,B.G.,andKutter,E.M.(2011).Phage treatmentofhumaninfections. Bacteriophage 1, 66-85.doi:10.4161/bact.1.2. 15845

10- Chanishvili,A.(2012). A LiteratureReviewofthePracticalApplicationof Bacteriophages. NewYorkCity:NovaSciencePublishers. 
11- Malik S, Sidhu PK, Rana JS, Nehra K.(2019) Managing urinary tract infections through phage therapy: a novel approach [published online ahead of print, 2019 Sep 7]. Folia Microbiol (Praha). 2019;10.1007/s12223-019-00750-y. doi:10.1007/s12223-019-00750-y

12- Twort FW (1915) An investigation on the nature of the ultramicroscopic viruses. Lancet 186:1241-1243. https://doi.org/10.1016/S0140-6736(01)20383-3

13- D'Herelle F (1917) On an invisible microbe antagonistic toward dysenteric bacilli: brief note by Mr. F. D'Herelle, presented by Mr. Roux.Res Microbiol 158:553-554. https://doi.org/10.1016/j.resmic.2007.07.005

14- Aminov RI (2010) A brief history of the antibiotic era: lessons learned and challenges for the future. FrontMicrobiol 1:1-7. https://doi.org/ 10.3389/fmicb.2010.00134

15- Xu Y, Liu Y, Liu Y, Pei J, Yao S, Cheng C.(2015) Bacteriophage therapy against Enterobacteriaceae. Virol Sin.;30(1):11-18. doi:10.1007/s12250-014-3543-6

16- Reed CA, Langlais C, Kuznetsov V, Young R. (2012). Inhibitory mechanism of the Q $\beta$ lysis protein A2. Mol Microbiol, 86:836-844.

17- Tanaka S, Clemons WM Jr.(2012). Minimal requirements for inhibition of MraY by lysis protein E from bacteriophage $\varphi$ X174. Mol Microbiol, 85:975-985.

18- McAuliffe O, Ross RP, Fitzgerals GF.( 200). The new phage biology: from genomics to applications. In Bacteriophage: Genetics and Molecular Biology (1st ed.). Mc Grath S and van Sinderen D.Norfolk, Engand: Caister Academic Press. pp. 1-42.

19- Fischetti VA.(2008). Bacteriophage lysins as effective antibacterials. Curr Opin Microbiol, 11:393-400.

20- Guo M, Feng C, Ren J, Zhuang X, Zhang Y, Zhu Y, Dong K, He P, Guo X, Qin J (2017) A novel antimicrobial Endolysin, LysPA26, against Pseudomonas aeruginosa. Front Microbiol 8:293. https://doi.org/ 10.3389/fmicb.2017.0029

21- Yen M, Cairns LS, Camilli A (2017) A cocktail of three virulent bacteriophages prevents Vibrio cholerae infection in animal models. Nat Commun 8:1-7. https://doi.org/10.1038/ncomms 14187

22- Gill JJ, Hyman P (2010) Phage choice, isolation and preparation for phage therapy. Curr Pharm Biotechnol 11:2-14

23- Nishikawa H, Yasuda M, Uchiyama J, Rashel M, Maeda Y, Takemura I,Sugihara S, Ujihara T, Shimizu Y, Shuin T, Matsuzaki S (2008) Teven-related bacteriophages as candidates for treatment of Escherichia coli urinary tract infections. Arch Virol 153:507515.https://doi.org/10.1007/s00705-007-0031-4

24- Chibeu A, Lingohr EJ, Masson L, Manges A, Harel J, Ackermann HW, Kropinski AM, Boerlin P (2012) Bacteriophages with the ability to degrade uropathogenic Escherichia Coli biofilms. Viruses 4:471- 487. https://doi.org/10.3390/v4040471

25- Chadha P, Katare OP, Chibber S (2016) In vivo efficacy of single phage versus phage cocktail in resolving burn wound infection in BALB/c mice. Microb Pathog 99:68-77

26- Jacobsen SM, Stickler DJ, Mobley HLT, ShirtliffME (2008) Complicated catheter-associated urinary tract infections due to Escherichia coli and Proteus mirabilis. ClinMicrobiol Rev 21:2659. https://doi.org/10.1128/CMR.00019-07 
27- Lehman SM, Donlan RM (2015) Bacteriophage-mediated control of a two-species biofilm formed by microorganisms causing catheterassociated urinary tract infections in an in vitro urinary catheter model. Antimicrob Agents Chemother 59:1127-1137. https://doi.org/10.1128/AAC.03786-14

28- Kelly D, McAuliffe O, Ross RP, Coffey A (2012) Prevention of Staphylococcus aureus biofilm formation and reduction in established biofilm density using a combination of phage $\mathrm{K}$ and modified derivatives. Lett Appl Microbiol 54:286-291. https://doi.org/10.1111/j.1472765X.2012.03205

29- Møller-Olsen C, Ho SFS, Shukla RD, Feher T, Sagona AP (2018) Engineered K1F bacteriophages kill intracellular Escherichia coli K1 in human epithelial cells. Sci Rep 8:17559. https://doi.org/10. 1038/s41598-018-35859-6

30- KimM, Jo Y, Hwang YJ, Hong HW, Hong SS, Park K,Myung H (2018) Phage antibiotic synergy via delayed lysis. Appl Environ Microbiol 84:e02085-e02018. https://doi.org/10.1128/AEM.02085-18

31- Ujmajuridze A, Chanishvili N, Goderdzishvili M, Leitner L, Mehnert U, Chkhotua A, Kessler TM, Sybesma W (2018) Adapted bacteriophages for treating urinary tract infections. Front Microbiol 9: 1832. https://doi.org/10.3389/fmicb.2018.01832

32- Khawaldeh A, Morales S, Dillon B, et al. Bacteriophage therapy for refractory Pseudomonas aeruginosa urinary tract infection (2011). J Med Microbiol.;60(Pt 11):1697-1700. doi:10.1099/jmm.0.029744-0

33- Leitner L, Sybesma W, Chanishvili N, et al. Bacteriophages for treating urinary tract infections in patients undergoing transurethral resection of the prostate: a randomized, placebo-controlled, double-blind clinical trial.(2017) BMC Urol.;17(1):90. Published 2017 Sep 26. doi:10.1186/s12894-017-0283-6 